\title{
Occurrence of Radiologically Detectable "Kissing" Lesion in Dog Elbows in Dependence on the Type of Fragmentation of the Processus Coronoideus Medialis and on Sex
}

\author{
Pavel Proks ${ }^{1}$, Ladislav Stehlík ${ }^{1}$, Katarína Irová1, Robert Srnec ${ }^{2}$, Petr Raušer ${ }^{2}$, \\ Milan Dvořák ${ }^{2}$, Alois Nečas ${ }^{2}$

\begin{abstract}
${ }^{1}$ Department of Diagnostic Imaging, Small Animal Clinic, Faculty of Veterinary Medicine, ${ }^{2}$ Department of Surgery and Orthopaedics, Small Animal Clinic, Faculty of Veterinary Medicine, University of Veterinary and
\end{abstract} \\ Pharmaceutical Sciences Brno, Czech Republic
}

Received March 6, 2009

Accepted December 3, 2009

\begin{abstract}
The aim of the study was to find the frequency of radiologically detectable "kissing" lesion in individual variants of fragmented processus coronoideus medialis (FCP) and its occurrence in relation to sex. The radiographs of elbow joints $(n=135)$ of dogs $(n=77)$ in which a fragmented processus coronoideus medialis ulnae was detected arthroscopically $(n=109)$ or arthrotomically $(n=26)$ were evaluated. Significantly higher occurrence of radiologically detectable "kissing" lesion was found in elbows with non-dislocated and dislocated fragment $(p<0.01)$. Significantly lower occurrence of radiologically detectable "kissing" lesion was found in elbows with chondromalacia of processus coronoideus medialis (PCM) $(p<0.01)$. We found no significant difference $(p>0.05)$ between the occurrence of a "kissing" lesion in males and females with FCP. The occurrence of the "kissing" lesion extending to the subchondral bone was not affected by sex. The results of our study suggest the possibility of identifying elbow joints with completely fragmented FCP on the basis of occurrence of a radiologically detectable "kissing" lesion.
\end{abstract}

Fragmented coronoid process, elbow, dog

Fragmented processus coronoideus medialis (FCP) of the elbow bone is the most frequently occurring developmental disease of the elbow joint in dogs (Wind and Packard 1986; Boulay 1998; La Fond et al. 2002; Meyer-Lindenberg et al. 2002; Gemmill et al. 2006). Considering the frequent occurrence of FCP in service and working breeds of dogs, this disease presents a serious economic problem for the owner (Gemmill and Clements 2007). An early diagnosis and therapy of FCP may prevent the development of osteoarthritis. The cause of origin of FCP is so far unknown. Genetic factors, fast growth, nutritional influences and trauma have been mentioned as possible causes of the origin of FCP (Yovich and Read 1994; Eckman and Carlson 1998; Maki et al. 2000; Maki et al. 2002). Some authors rank FCP among the osteochondrosis complex (Bennet et al. 1981; Grøndalen and Grøndalen 1981; Eckman and Carlson 1998). Other studies consider temporary or permanent incongruity of articular surfaces of the elbow joint as a possible cause of FCP (Guthrie et al. 1992; Fitzpatrick and O'Riordan 2004). FCP frequently occurs independently, or less frequently in combination with osteochondritis dissecans (OCD) of the medial humeral condyle or ununited anconeal process (UAP) (Guthrie and Pidduck 1990; Meyer-Lindenberg et al. 2002; Rovesti et al. 2002; Meyer-Lindenberg 2006). Large breeds of dogs are affected most frequently. The most often affected breeds include the Labrador retriever, Golden retriever, Rottweiler, Bernese mountain dog, Mastiff, German shepherd and Chow-chow (Boulay 1998; Morgan et al. 2000; La Fond et al. 2002; Bissenik et al. 2005; Kirberger and Stander 2007). However, FCP has also been found in small breeds of dogs and mongrels (Boulay 1998). Males are affected more often than females (Read et al. 1990; Grøndalen and Lingas 1991; 
Huibregste et al. 1994; Morgan et al. 1999; Kirberger and Stander 2007). The disease is usually bilateral, while it may be clinically manifested only in one extremity (Grøndalen 1982; Olsson 1983). In FCP diagnostics, radiological examination of elbow joints is commonly used. In unclear cases, FCP may be diagnosed using computed tomography (Rovesti et al. 2002) or by arthroscopic examination of the elbow joint (Bissenik et al. 2005). According to the appearance of processus coronoideus medialis (PCM) during arthroscopic examination the FCP is classified into seven types (Bardet 1997; Griffon 2006). During X-ray diagnostics, direct radiological visualisation of FCP is not usually possible, because of the close contact of PCM with the radial head (Carpenter et al. 1993; Keller et al. 1997). In such cases, FCP is radiologically detected indirectly based on the presence of articular surface incongruity and non-specific secondary osteoarthritic changes. In some cases a radiolucent defect on the medial humeral condyle known as the "kissing" lesion can be found on craniocaudal radiographs of the elbow joint. The "kissing" lesion is one of the indirect radiological evidence of FCP and is caused by mechanical irritation of the opposite medial humeral condyle by fragmented PCM (Morgan et al. 2000). Native radiographs can only show a "kissing" lesion extending to the subchondral bone. However, a "kissing" lesion of the articular cartilage of the medial humeral condyle has been found pre-operatively even in a case of fissured and chondromalatic PCM (Meyer-Lindenberg et al. 2003). Yet, it is unknown whether there is a relationship between radiologically identifiable "kissing" lesion and the type of FCP. It is also unknown whether the occurrence of a "kissing" lesion is affected by sex of the animal.

The aim of this study was to find the frequency of radiologically identifiable "kissing" lesion in the elbow joints with FCP in individual types of FCP and also the occurrence of a "kissing" lesion in relation to sex. Null hypothesis presumed that there is no significant difference in the frequency of "kissing" lesions in individual variants of FCP and in the frequency of "kissing" lesions between the sexes of dogs with FCP. An alternative hypothesis presumed that there is a significant difference in the frequency of "kissing" lesions in individual variants of FCP and in the frequency of "kissing" lesions between the sexes of dogs.

\section{Materials and Methods}

Inclusion criteria

The retrospective study evaluated 135 elbow joints of 77 dogs with surgically treated fragmentation of the processus coronoideus medialis. A total of 135 elbow joints of dogs with FCP and with the necessary complete records of the type of FCP during arthroscopic or arthrotomic treatment were chosen from the medical records of the Department of Surgery and Orthopaedics of the Small Animal Clinic, Faculty of Veterinary Medicine, University of Veterinary and Pharmaceutical Sciences, Brno in the period of 2001-2008. The study did not include elbows with concurrent FCP and OCD in the medial humeral condyle, elbows with concurrent FCP and UAP, and elbows in which the oblique craniocaudal projection (Cr15L-CaMO) was not done. One-hundred and nine elbow joints were treated arthroscopically and 26 elbow joints were treated arthrotomically. The group comprised 63 males and 14 females.

Radiography

In all elbow joints included in the study, mediolateral (ML) radiographs in the standing angle and oblique craniocaudal projection (Cr15L-CaMO) were made. All radiographs were done with patients under deep intravenous sedation induced by combination of medetomidine (10-20 $\mu \mathrm{g} / \mathrm{kg}$ i.v. $)$ and butorphanol $(0.2 \mathrm{mg} / \mathrm{kg}$ i.v.), or in general intravenous anaesthesia (medetomidine 10-20 $\mu \mathrm{g} / \mathrm{kg}$ i.v., butorphanol 0.2 mg/kg i.v., propophol $1 \mathrm{mg} / \mathrm{kg}$ i.v.). Radiographs were done on the X-ray machine Proteus XR/a without the use of a grid, with the cassette placed immediately under the elbow joint. Patients were positioned by employees of the Department of Diagnostic Imaging acquainted with the technique of correct positioning of the elbow joint. Radiographs of 105 elbows were made on X-ray films using intensifying screen with the screen speed 100, or on mammographic cassettes and films. Radiographs of 30 elbows were made in the digital form in the DICOM format at a resolution of $1170 \times 2370$ px $($ CR, Fuji, Capsula XL). The presence of a "kissing" lesion was assessed subjectively by one observer based on the radiographs done in the craniocaudal oblique projection. As a "kissing" lesion, a radiolucent defect in the subchondral bone of the medial humeral condyle proximally from the PCM was considered, that was not concurrently identified in the operational protocol as osteochondrosis of the medial humeral condyle.

FCP classification

In each elbow, the FCP variant was recorded from the operational protocol. We used the FCP classification 
that is commonly used at our department (Department of Surgery and Orthopaedics of the Small Animal Clinic, University of Veterinary and Pharmaceutical Sciences Brno) based on a modification of the arthroscopic classification of FCP variants (Bardet 1997; Griffon 2006). We divided FCP by its appearance during the arthroscopic (arthrotomic) treatment into seven types - fragmentation on the medial margin of PCM, erosion of the lateral rim of PCM, fissured PCM, non-dislocated fragment of PCM, dislocated fragment of PCM, chondromalacia of PCM, and osteophytes on PCM. All surgical procedures were performed and evaluated by experienced orthopaedic surgeons.

Statistical analysis

We found the absolute and relative frequency of radiologically detectable "kissing" lesion in elbows with FCP. We compared the absolute and relative frequency of the occurrence of a "kissing" lesion as well as the difference between the actual and anticipated frequencies in individual types of FCP. Furthermore, we compared the absolute and relative occurrence of and difference between the actual and anticipated frequencies of "kissing" lesions in males and females. Statistical analysis of the data on the occurrence of "kissing" lesions in individual FCP variants was done using the calculation of Freeman-Turkey's deviation. For statistical analysis of the occurrence of "kissing" lesions in relation to sex Fisher's exact test was used.

\section{Results}

Of the total number of 135 elbows of 77 dogs, a "kissing" lesion occurred in 39 elbows of 30 dogs. In 9 cases the "kissing" lesion occurred in elbow joints bilaterally, in 21 cases unilaterally. The absolute and relative frequencies of a "kissing" lesion occurrence in individual types of FCP is presented in Table 1. In elbow joints with non-dislocated fragment of PCM as well as in elbow joints with dislocated fragment of PCM, significantly higher occurrence of "kissing" lesions $(p<0.01)$ was found. In contrast, elbow joints with arthroscopically/arthrotomically proven chondromalacia showed significantly lower occurrence of "kissing" lesions $(p<0.01)$. In elbow joints with fragmented medial margin of PCM, erosion of the lateral rim of PCM, fissured PCM and osteophytes on PCM, no significant difference between the actual and anticipated frequencies of "kissing" lesion occurrence was found.

Table 1. Absolute and relative frequency of "kissing" lesions and individual FCP variants

\begin{tabular}{|l|c|c|c|}
\hline \multicolumn{1}{|c|}{ "Kissing" lesion } & $\begin{array}{c}\text { Positive finding } \\
\text { Absolute } \\
\text { frequency (\%) }\end{array}$ & $\begin{array}{c}\text { Negative finding } \\
\text { Absolute } \\
\text { frequency (\%) }\end{array}$ & $\begin{array}{c}\text { Total } \\
\text { Absolute } \\
\text { frequency (\%) }\end{array}$ \\
\hline $\begin{array}{l}\text { Fragmented medial } \\
\text { margin of PCM }\end{array}$ & $0(0)$ & $3(2.22)$ & $3(2.22)$ \\
\hline $\begin{array}{l}\text { Eroded lateral } \\
\text { rim of PCM }\end{array}$ & $2(1.48)$ & $2(1.48)$ & $4(2.96)$ \\
\hline Fissured PCM & $1(0.74)$ & $6(4.44)$ & $7(5.18)$ \\
\hline Non-dislocated fragment of PCM & $14^{*}(10.37)^{* *}$ & $21(15.57)$ & $35(25.94)$ \\
\hline Dislocated fragment of PCM & $20^{*}(14.81)^{*}$ & $24(17.78)$ & $44(32.59)$ \\
\hline Chondromalacia of PCM & $1(0.74)$ & $36^{*}(26.67)^{* *}$ & $37(27.41)$ \\
\hline Osteophytes on PCM & $1(0.74)$ & $4(2.96)$ & $5(3.70)$ \\
\hline Total & $39(28.88)$ & $96(71.12)$ & $135(100.00)$ \\
\hline
\end{tabular}

$* p<0.01$

No significant difference was found in the occurrence of "kissing" lesions in relation to sex $(p>0.05)$. The absolute and relative frequencies of "kissing" lesions in relation to sex are presented in Table 2 .

\section{Discussion}

The "kissing" lesion is defined as erosion of articular cartilage and subchondral bone of the medial humeral condyle in the place of the contact of PCM with the elbow bone (Van Ryssen and Van Bree 1997). The "kissing" lesion is probably caused by mechanical irritation of articular cartilage and subchondral bone of the medial humeral condyle by ossified proximally prominent PCM or FCP (Hazewinkel 2008). 
Table 2. Absolute and relative frequency of radiologically detectable kissing lesion in relation to sex

\begin{tabular}{|l|c|c|c|}
\hline Sex & $\begin{array}{c}\text { "Kissing" lesion positive } \\
\text { Absolute frequency (\%) }\end{array}$ & $\begin{array}{c}\text { "Kissing" lesion negative } \\
\text { Absolute frequency (\%) }\end{array}$ & $\begin{array}{c}\text { Total } \\
\text { Absolute frequency (\%) }\end{array}$ \\
\hline Male & $26(33.77)$ & $37(48.05)$ & $63(81.82)$ \\
\hline Female & $4(5.19)$ & $10(12.99)$ & $14(18.18)$ \\
\hline Total & $30(38.96)$ & $47(61.04)$ & $77(100.00)$ \\
\hline
\end{tabular}

Radiologically the "kissing" lesion is identifiable on the craniocaudal $(\mathrm{CrCa})$ and craniocaudal oblique projection of the elbow joint (Miyabayashi et al. 1995; Wosar et al. 1999). In this study, the presence of a "kissing" lesion was assessed on the basis of evaluation of oblique craniocaudal (Cr-15LCaMO) radiographs of the elbow joint. Since all radiographs were evaluated only by the author of this study, subjective assessment of the presence of a "kissing" lesion may be considered as sufficient for the purpose of this study.

"Kissing" lesion was found in 28\% (39/135) cases, most frequently located in elbow joints with completely fragmented cranial apex of PCM. In elbows with a free dislocated fragment of FCP, "kissing" lesion was found in 14.81\% (20/135) cases, and in elbows with non-dislocated fragment of the processus coronoideus medialis in $10.37 \%(14 / 135)$ cases. A "kissing" lesion was rarely observed in elbow joints with fissured PCM $(0.74 \%)$ $(1 / 135)$, chondromalacia of PCM $(0.74 \%)(1 / 135)$, osteophytes on the articular surface of PCM $(0.74 \%)(1 / 135)$ and eroded lateral border of PCM (1.48\%) (2/135). In elbows with fragmented medial margin of PCM we found no presence of a "kissing" lesion.

In elbows with non-dislocated and dislocated fragment of PCM we found significantly higher occurrence of "kissing" lesions $(p<0.01)$ compared to the anticipated occurrence. In contrast, in elbows with chondromalacia of PCM we found significantly lower occurrence of "kissing" lesions $(p<0.01)$ than anticipated. The higher occurrence of radiologically detectable "kissing" lesions in elbow joints with non-dislocated and dislocated fragments of FCP and on the contrary the lower frequency of radiologically identifiable "kissing" lesions in elbow joints with chondromalacia of PCM support the theory of a mechanical origin of the "kissing" lesion (Morgan et al. 2000). It may be assumed that the malatic cranial apex of PCM mechanically irritates the medial articular surface of the humeral condyle to a lesser extent than an ossified free fragment of the cranial apex of PCM. Van Ryssen and Van Bree (1997) found "kissing" lesions in a group of 131 arthroscopically treated elbows with FCP in $66.1 \%$ cases. In $48.88 \%$ cases the "kissing" lesion was observed in connection with fragmented FCP, in $6.88 \%$ in connection with fissured PCM, and in $6.1 \%$ in connection with chondromalacia of PCM. In our study we assessed the presence of a "kissing" lesion based on native radiographs. Practically we were able to detect only the "kissing" lesions that extend to the subchondral bone and are manifested on radiographs as a radiolucent defect in the subchondral bone. Articular erosions that may be identified only arthroscopically are unidentifiable on native radiographs. Radiological evaluation of the presence of a "kissing" lesion in elbow joints is highly subjective and no criteria for its evaluation are known. Therefore, in some cases the radiological finding of a "kissing" lesion may be confused with osteochondrosis of the medial humeral condyle.

Although FCP is much more frequently diagnosed in males (Read et al. 1990; Grøndalen and Lingas 1991; Huibregste et al. 1994; Morgan et al.1999; Salg et al. 2006; Kirberger and Stander 2007), we found no significant difference between the actual and anticipated frequencies $(p>0.05)$ of the occurrence of a radiologically detectable "kissing" lesion and sex. Therefore, the occurrence of a "kissing" lesion is probably not directly affected by the presence of sex hormones but is probably caused by mechanical irritation of the articular cartilage and subchondral bone of the medial humeral condyle by a fragment of PCM or by proximally prominent cranial apex of PCM. 
From the results of the study we may draw the clinically important conclusion that in elbow joints with a "kissing" lesion extending to the subchondral bone, complete fragmentation of the cranial of PCM (non-dislocated fragment of FCP, or dislocated fragment of FCP) may be expected. When radiologically detectable "kissing" lesion is not present in elbow joints with FCP, chondromalacia of PCM may be expected. While the fragment of PCM alone might not be radiologically visible, the presence of radiologically detectable "kissing" lesion may help specify FCP diagnostics with regard to the subsequent decision on possible indications for surgical treatment of FCP.

\section{Výskyt rentgenologicky detekovatelné „kissing“6 léze v loketních kloubech psů v závislosti na typu fragmentace processus coronoideus medialis a pohlaví}

Cílem studie bylo zjistit četnost rentgenologicky identifikovatelné „kissing“ léze u jednotlivých variant fragmentace processus coronoideus medialis (FCP) a její výskyt ve vtahu k pohlaví. Hodnoceny byly rentgenogramy loketních kloubů $(n=135)$ psů $(\mathrm{n}=77)$, u nichž byl artroskopicky $(\mathrm{n}=109)$ nebo artrotomicky $(\mathrm{n}=26)$ prokázán fragmentovaný processus coronoideus medialis ulnae (PCM). Signifikantně vyšší výskyt rentgenologicky identifikovatelné „kissing“ léze byl zaznamenán u loketních kloubů s nedislokovaným a dislokovaným fragmentem $(p<0,01)$. Signifikantně nižší výskyt rentgenologicky identifikovatelné „kissing“ léze byl zaznamenán u loketních kloubů s chondromalácií PCM $(p<0,01)$. Mezi výskytem „kissing“ léze u psů a fen s FCP nebyl zaznamenán významný rozdíl $(p>0,05)$. Výskyt „kissing“ léze zasahující do subchondrální kosti nebyl ovlivněn pohlavím.

Výsledky naší studie naznačují možnost identifikovat loketní klouby s kompletně fragmentovaným FCP na základě výskytu rentgenologicky detekovatelné „kissing“ léze.

\section{References}

Bardet JF 1997: Arthroscopy of the elbow in dogs Part II: The normal arthroscopic anatomy using the craniolateral portal. Vet Comp Orthopaed 10: 60-66

Bennet D, Duff SRI, Kene RO, Lee R 1981: Osteochondritis dissecans and fragmentation of the coronoid process in the elbow joint of the dog. Vet Rec 109: 329-336

Bissenik I, Galanty M, Kupczynska M, Makowiecka, M 2005: Rozpoznawanie i leczenie dysplazji stawu lokciowego u psów z wykorzystaniem artroskopii. Med Weter 61: 401-404

Boulay JP 1998: Fragmented medial coronoid process of the ulna in the dog. Vet Clin N Am-Small 28: 51-72

Carpenter L, Schwarz P, Lowry J, Park RD, Steyn PF 1993: Comparison of radiologic imaging techniques for diagnosis of fragmented medial coronoid process of the cubital joint in dogs. J Am Vet Med Assoc 203: 78-83

Eckman S, Carlson CS 1998: The pathophysiology of osteochondrosis. Vet Clin N Am-Small 28: 17-32

Fitzpatrick MN, O’Riordan J 2004: Clinical and radiographic assessment of 83 cases of subtotal coronoidectomy (SCO) for treatment of fragmented medial coronoid process. Proceedings of the BSAVA Congress, Clinical Research Abstracts, Brimingham, p. 594

Gemmill TJ, Clements DN 2007: Fragmented coronoid process in the dog: is there a role for incongruency? J Small Anim Prac 48: 361-368

Gemmill TJ, Hammond G, Mellor DJ, Sullivan M, Bennett D, Carmichael S 2006: Use of reconstructed computed tomography for the assessment of joint spaces in the canine elbow. J Small Anim Prac 46: 66-67

Griffon DJ 2006: Controversies in arthroscopic treatment of FCP. Proceedings of the WSAVA Congress, WSAVA, Prague, pp. 634-636

Grøndalen J 1982: Arthrosis in the elbow joint of young rapidly growing dogs VII. Occurrence in the Rottweiler dogs. Nord Vet Med 34: 76-82

Grøndalen J, Grøndalen T1981: Arthrosis in the elbow joint of young rapidly growing dogs V. A pathoanatomical investigation. Nord Vet Med 31: 69-75

Grøndalen J, Lingaas F 1991: Arthrosis in the elbow joint of young rapidly growing dogs: A genetic investigation. J Small Anim Prac 32: 460-464

Guthrie S, Pidduck HG 1990: Heritability of elbow osteochondritis within a closed population of dogs. J Small Anim Prac 31: 93-96

Guthrie S, Plummer JM, Vaughan LC 1992: Aethiopatogenesis of canine elbow osteochondrosis: A study of loose fragments removed at arthrotomy. Res Vet Sci 52: 284-291

Huibregste BA, Johnson AL, Muhlbauer MC, Piljanowski GJ 1994: The effect of treatment of fragmented coronoid process on the development of osteoarthrosis of the elbow. J Am Anim Hosp Assoc 30: 190-195 
Keller G, Kreeger J, Mann F, Fred A, Lattimer LC 1997: Correlation of radiographic, necropsy and histologic findings in 8 dogs with elbow dysplasia. Vet Radiol Ultrasound 38: 272-276

Kirberger RM, Stander N 2007: Incidence of canine elbow dysplasia in South Africa. J S Afr Vet Assoc 78: 9-62

La Fond E, Breur GJ, Austin CC 2002. Breed susceptibility for developmental orthopedic diseases in dogs. J Am Anim Hosp Assoc 38: 467-477

Maki K, Liinamo AE, Ojala M 2000: Estimates of genetic parameters for hip and elbow dysplasia in Finnish Rottweilers. J Anim Sci 78: 1141-1148

Maki K, Liinamo AE, Ojala M 2002: Genetic variances, trends and modes of inheritance for hip and elbow dysplasia in Finnish dog populations. J Anim Sci 75: 197-207

Meyer-Lindenberg A, Fehr M, Nolte I 2006: Coexistence of ununited anconeal process and fragmented medial coronoid process of the ulna in the dog. J Small Anim Prac 47: 61-65

Meyer-Lindenberg A, Langhan A, Fehr M, Nolte I 2002: Prevalence of fragmented medial coronoid process of the ulna in lame adult dogs. Vet Rec 151: 230-234

Meyer-Lindenberg A, Langhann A, Fehr M 2003: Arthrotomy versus arthroscopy in the treatment of fragmented coronoid process of the ulna (FCP) in 421 dogs. Vet Comp Orthopaed 16: 204-210

Miyabayashi T, Takiguchi M, Schrader SC 1995: Radiographic evaluation of the medial coronoid process of dogs. J Am Anim Hosp Assoc 31: 125-132

Morgan JP, Wind AP, Davidson AP 1999: Bone dysplasias in the labrador retriever: A radiographic study: J Am Anim Hosp Assoc 35: 332-340

Morgan JP, Wind AP, Davidson AP 2000: Elbow dysplasia. In: Morgan JP, Wind AP, Davidson AP: Hereditary bone and joint diseases in the dog. Schlutersche GmbH, Hannover, pp. 41-94

Olsson SO 1983. The early diagnosis of fragmented coronoid process and osteochondritis dissecans of the canine elbow joint. J Am Anim Hosp Assoc 19: 616-626

Read RA, Armstrong SJ, O'Keefe JD, Eger CE 1990: Fragmentation of the medial coronoid process of the ulna in dogs: A study of 109 cases. J Small Anim Pract 31: 330-334

Rovesti GL, Biasibetti M, Schumacher A, Fabian M 2002: The use of computed tomography in the diagnostic protocol of the elbow in the dog: 24 joints. Vet Comp Orthopaed 15: 35-43

Salg KG, Temwitchitr J, Imholz S, Hazewinkel HA, Legwater PA 2006: Assessment of collagen genes involved in fragmented medial coronoid process development in Labrador Retrievers as determined by affected siblingpair analysis. Am J Vet Res 67: 1713-1718

Van Ryssen B, Van Bree H 1997: Arthroscopic findings in 100 dogs with elbow lameness Vet Rec 140: 360-362

Wind AP, Packard ME 1986: Elbow incongruity and development elbow diseases in the dog: Part II. J Am Hosp Assoc 22: 725-730

Wosar M, Lewis D, Neuwirth L, Parker R 1999: Radiographic evaluation of elbow joints before and after surgery in dogs with possible fragmented medial coronoid process. J Vet Med Assoc 214: 52-58

Yovich JC, Read RA1994: Traumatic fracture of the medial coronoid process in two dogs. Vet Comp Orthopaed 7: $173-176$ 